\author{
- убер, - ерезяк \\ ввівський н ціон льний університет імені в н \\ вул. . орошенк , 41, м. ьвів, 79000, кр їн
}

д ними метеост нцій ожижевськ і ремче визн чено клім тичну норму темпер тури повітря т кількості оп дів з період 1961-1990 pp. і про н лізов но відхилення середньої темпер тури повітря т кількості оп дів з період 2007-2009 рр. від їхньої клім тичної норми для орногірського л ндш фту исокогірно- олонинської і юбіжнянського л ндш фту изькогірнокибової фізико-геогр фічних обл стей кр їнських рп т у б сейні р. рут для з'ясув ння тенденцій клім тичних змін території дослідження.

ля періоду 2007-2009 рр. з фіксов но перевищення клім тичної норми темпер тури повітря н $1,3^{\circ}$ у орногірському л ндш фті (мст ожижевськ ) і н $1,6^{\circ}$ у юбіжнянському л ндш фті (мст ремче). еревищення кількості оп дів н д їхньою клім тичною нормою у орногірському л ндш фті ст новить 383,6 мм, в юбіжнянському - 155,2 мм.

лючові слов : тмосферні оп ди, темпер тур повітря, клім тичн норм, дин мік, л ндш фт.

ивчення клім тичних змін для території кр їни перебув є сьогодні в полі зору 6 г тьох дослідників [1, 12-14]. собливості клім тичних умов кр їнських рп т викл дені в низці публік цій $[2-4,9,10]$. ст ннім десятиліттям н укові пр ці з досліження клім тичних умов території 6 сейну р. рут у меж х рп т спрямов ні н 3'ясув ння термічних вл стивостей топоклім ту цієї території [11], рекре ційної оцінки метеоумов середньогір'я л ндш фту орногори [6]. огляду н висотну диференці цію території $б$ сейну гірського руту особливо в жливими є н ліз зміни пок зників темпер тури повітря т кількості оп дів н підст ві д них двох метеост нцій (мст) ожижевської (розт шов н у орногірському л ндш фті исокогірно- олонинської фізико-геогр фічної обл сті кр їнських рп т н висоті 1450 м) т ремч (розт шов н у юбіжнянському л ндш фті изькогірно- кибової обл сті н висоті 530 м).

ш мет - викон ти порівняльний н ліз усередненої темпер тури повітря і кількості оп дів з період 2007-2009 рр. з їі клім тичною нормою у орногірському високогірному т юбіжнянському низькогірному л ндш фт х для з'ясув ння тенденцій клім тичних змін території б сейну верхів'я р. рут у меж х рп т.

ервинними м тері л ми слугув ли д ні метеост нцій ожижевськ і ремч [8], н підст ві яких з період 1961-1990 рр. ми визн чили середні б г торічні зн чення темпер тури повітря і кількості оп дів, які є клім тичною нормою кожного 3 пок зників [15]. лім тичн норм метеорологічних величин (темпер тури повітря, кількості оп дів т ін.) - це середнє б г торічне зн чення, розр хов не відповідно до вимог сесвітньої метеорологічної орг ніз ції, з 30-річний період [16]. оніторинг погоди прийнято пров дити усередненням н йпростіших (у розумінні користув чів) ст тистич-

(C) убер ., ерезяк ., 2012 
них величин, якими є відхилення від норми ( бо ном лії) [16]. лім тичну норму темпер тури повітря розуміють як середнє б г торічне зн чення, перев жно з тридцятирічний період. ї оцінк грунтується н д них розр хунків середньої добової темпеp тури повітря (з д ними восьми з тригодинними інтерв л ми вимірюв нь) і середньої місячної темпер тури повітря із 30 бо 31 середніх добових зн чень. епловий ст н к ленд рних періодів (доб, місяць, сезон, рік) визн ч ють 3 відхиленнями від відповідних норм [17]. гідно з вимог ми сесвітньої метеорологічної орг ніз ції, під клім тичною нормою кількості оп дів розуміють середне 6 г торічне зн чення кількості оп дів, перев жно 3 30-річний період. цінк клім тичної норми кількості оп дів грунтується н д них розр хунків місячної і річної кількості оп дів (н підст ві д них вимірюв нь 3 кожну добу). т н зволоження к ленд рних періодів (доб , місяць, сезон, рік) визн ч ють $з$ відхиленням від відповідних норм [18].

лежно від клім тичної норми темпер тури повітря і кількості оп дів кожен рік $є$ теплішим бо холоднішим, з більшою бо меншою кількістю оп дів. ля з'ясув ння тенденцій змін темпер тури повітря і кількості оп дів у орногірському високогірному т юбіжнянському низькогірному л ндш фт х у б сейні р. рут н підст ві д них зг д них вище метеост нцій ми вибр ли період 2007-2009 pp., у якому проведено н ліз відхилень усереднених з три роки пок зників темпер тури повітря і кількості оп дів від їхньої клім тичної норми з період 1961-1990рр., вр ховуючи їхні зн чення по місяцях, з пор ми року і для року з г лом.

етеост нція ожижевськ розміщен н висоті 1450 м у исокогірно- олонинській фізико-геогр фічній обл сті в орногірському л ндш фті у висотній місцевості крутосхилого ерозійно-денуд ційного помірно холодного вологого лісистого середньогір'я $з$ п нув нням смерекових лісів н гірських бурозем х [5]. етеост нція ремч розт шов н н висоті 530 м у ередньогірно- кибовій фізико-геогр фічній обл сті в юбіжнянському л ндш фті у висотній місцевості тер сов ного днищ долин р. рут $з$ прохолодним вологим клім том і рік ми п водкового режиму з форм ціями сірої вільхи і вторинними різнотр вними лук ми н бурих гірсько-лісових і дерново-буроземних грунт x [5]. гідно з вертик льною термічною зон льністю, визн ченою . . ндріновим, метеост нція ожижевськ є у помірно холодній зоні, метеост нція ремч у помірній [2].

г льні тенденції змін темпер тури повітря і кількості оп дів 3 період 20072009 рр. ередня темпер тур повітря з 2007-2009 рр. бул вищою від ії клім тичної норми (з період 1961-1990 рр.) в орногірському л ндш фті н 1,3 ${ }^{\circ}$, у юбіжнянському - н $1,6^{\circ}$ (середні темпер тури повітря, відповідно, ст новили 4,0 і 8,5 ${ }^{\circ}$, клім тичні норми - 2,7 і $\left.6,9^{\circ}\right)$.

ередня річн кількість оп дів 3 період 2007-2009 рр. бул більшою від клім тичної норми (з період 1961-1990рр.) у орногірському л ндш фті н 383,6 мм, що в 1,3 р з перевищує клім тичну норму кількості оп дів, у юбіжнянському л ндш фті - н 155,2 мм, що в 1,2 р з більше від клім тичної норми кількості оп дів у юбіжнянському л ндш фті (середньорічн кількість оп дів, відповідно, ст новил 1 781,2 і 1 076,4 мм, клім тичн норм - 1 397,6 і 921,2 мм).

енденції змін темпер тури повітря і кількості оп дів по сезон $x$. ередня темпер тур повітря н весні з 2007-2009 рр. бул вищою від їі клім тичної норми у орногірському л ндш фті н $1,2^{\circ}, \quad$ у юбіжнянському л ндш фті - н $1,6^{\circ}$ (т бл. 1). 
весняний період 2007-2009 рр. середня кількість оп дів відрізнял ся від клім тичної норми - у орногірському л ндш фті кількість оп дів збільшил ся н 146,2 мм, що в 1,4 р 3 перевищує клім тичну норму кількості оп дів, у юбіжнянському зменшил ся в середньому н 1,7 мм, що незн чно відрізняється від клім тичної норми кількості оп дів н весні (т бл. 2).

ередня темпер тур повітря влітку з 2007-2009 рр. перевищув л клім тичну норму у орногірськомул ндш фті н $2,4^{\circ}$, у юбіжнянському-н $1,8^{\circ}$ (див. т бл. 1).

ереднє зн чення темпер тури повітря з пор ми року у 2007-2009 рр.

блиця 1.

\begin{tabular}{|c|c|c|c|}
\hline $\begin{array}{r}\text { ори } \\
\text { року }\end{array}$ & $\begin{array}{c}\text { ередня темпер тур } \\
\text { повітря, }\end{array}$ & $\begin{array}{c}\text { лім тичн норм } \\
\text { темпер тури повітря, }\end{array}$ & $\begin{array}{c}\text { ідхилення від клім тичної } \\
\text { норми середньої темпер тури } \\
\text { повітря, }\end{array}$ \\
\hline \multicolumn{3}{|c|}{$\begin{array}{c}\text { орногірський л ндш фт } \\
\text { (мст ожижевськ })\end{array}$} \\
\hline есн & 3,0 & 1,8 & 1,2 \\
\hline іто & 13,3 & 10,9 & 2,4 \\
\hline сінь & 4,1 & 3,7 & 0,4 \\
\hline им & $-4,4$ & $-5,7$ & 1,3 \\
\hline \multicolumn{5}{|c|}{$\begin{array}{c}\text { юбіжнянський л ндш фт } \\
\text { (мст ремч) }\end{array}$} \\
\hline есн & \multicolumn{4}{|c|}{6,8} \\
\hline іто & 17,6 & 15,8 & 1,6 \\
\hline сінь & 8,3 & 7,5 & 1,8 \\
\hline им & $-0,5$ & $-2,4$ & 1,8 \\
\hline
\end{tabular}

літній період 2007-2009 рр. середня кількість оп дів бул більшою від клім тичної норми у орногірському л ндш фті н 40,8 мм, що в 1,1 р 3 перевищує клім тичну норму, у юбіжнянському н 58,9 мм, що т кож в 1,1 р з більше від клім тичної норми (див. т бл. 2). зн чимо, що м ксим льн кількість оп дів улітку 20072009 pр. у орногірському л ндш фті з фіксов н 2008 р. - 697,9 мм, що н 206,3 мм більше від клім тичної норми, у юбіжнянському л ндш фті - т кож 2008 р. - 686,7 мм, що н 255,7 мм більше від клім тичної норми. собливо зн чн кількість оп дів з реєстров н в ост нній дек ді липня, зокрем , у орногірському л ндш фті їхня кількість ст новил 287,3 мм, в юбіжнянському - 351,2 мм, що і призвело до виникнення к т строфічного п водку у верхів’ї р. рут 26-27 липня 2008 р. [7].

ередня темпер тур повітря восени у 2007-2009 рр. бул вищою від ії клім тичної норми у орногірськомул ндш фті н $0,4^{\circ}$, у юбіжнянському-н $0,8^{\circ}$

осінній період 2007-2009 рр. середня кількість оп дів більш від клім тичної норми у орногірському л ндш фті н 97,3 мм, що в 1,3 р з перевищує клім тичну норму оп дів, у юбіжнянському - н 81,2 мм, що в 1,5 р з більше від клім тичної норми оп дів восени для мст ремч .

ередня темпер тур повітря взимку з 2007-2009 pр. перевищув л клім тичну норму у орногірському л ндш фті н $1,3^{\circ}$, у юбіжнянському $-\mathrm{H} 1,9^{\circ}$ (див. т бл. 1). зимовий період 2007-2009 рр. середня кількість оп дів виявил сь більшою від клім тичної норми у орногірському л ндш фті н 99,3 мм, що в 1,4 р з перевищує 
клім тичну норму, у юбіжнянському - н 16,8 мм, що в 1,2 р з більше від клім тичної норми оп дів узимку (див. т бл. 2).

блиця 2

ереднє зн чення кількості оп дів з пор ми року в 2007-2009 pp.

\begin{tabular}{|c|c|c|c|}
\hline ори року & $\begin{array}{l}\text { ередня кількість } \\
\text { оп дів, мм }\end{array}$ & $\begin{array}{c}\text { лім тичн } \\
\text { кількості оп } \\
\text { дів, мм }\end{array}$ & $\begin{array}{c}\text { ідхилення від } \\
\text { клім тичної норми } \\
\text { кількості оп дів, мм }\end{array}$ \\
\hline \multicolumn{4}{|c|}{$\begin{array}{l}\text { орногірський л ндш фт } \\
(\text { мст ожижевськ ) }\end{array}$} \\
\hline ecH & 472,8 & 326,6 & 146,2 \\
\hline іто & 532,4 & 491,6 & 40,8 \\
\hline сінь & 413,6 & 316,3 & 97,3 \\
\hline им & 362,4 & 263,1 & 99,3 \\
\hline \multicolumn{4}{|c|}{$\begin{array}{l}\text { юбіжнянський л ндш фт } \\
(\text { мст ремч ) }\end{array}$} \\
\hline ecH & 237,1 & 238,8 & $-1,7$ \\
\hline іто & 467,5 & 408,6 & 58,9 \\
\hline сінь & 250,2 & 169,0 & 81,2 \\
\hline им & 121,6 & 104,8 & 16,8 \\
\hline
\end{tabular}

енденції змін темпер тури повітря по місяцях. ля кожного місяця впродовж року х р ктерним є нерівномірне відхилення середньої темпер тури повітря від її клім тичної норми (т бл. 3). орногірському л ндш фті з період 2007-2009 pр. н йбільше перевищення клім тичної норми середньої темпер тури повітря спостеріг ли у січні $\left(1,9^{\circ}\right)$, червні $(2,0)$, липні $(2,4)$ т серпні $(2,7)$. цей же період у юбіжнянському л ндш фті н йбільше перевищення клім тичної норми середньої темпер тури повітря х р ктерне для січня $\left(3,4^{\circ}\right)$, червня $(1,8)$, липня $(1,7)$, серпня $(1,9)$ т листоп д $\left(2,2^{\circ}\right)$. г лом з зн чимо, що н йбільше перевищення клім тичних норм середньої темпер тури повітря для кожного зі зг д них вище л ндш фтів прит м нні для н йтепліших і н йхолодніщих місяців року (див. т бл. 3). н ліз відхилення від клім тичних норм між двом л ндш фт ми свідчить про те, що н йбільші відмінності х р ктерні для січня $\left(1,5^{\circ}\right)$, лютого $(1,6)$ т грудня $\left(1,3^{\circ}\right)$, причому із січня по тр вень зн чніші дод тні відхилення від норми спостеріг ють у юбіжнянському л ндш фті, тоді як у орногірському - включно із червня по грудень.

3н чимо, що н йтеплішим місяцем року з період 2007-2009 pp. щодо клім тичної норми середньої темпер тури повітря у орногірському л ндш фті є серпень (н $2,7^{\circ}$ вище від клім тичної норми), у юбіжнянському - січень $\left(3,4^{\circ}\right)$.

енденції змін кількості оп дів по місяцях. ля всіх місяців х р ктерним є відхилення кількості оп дів від їхньої клім тичної норми. окрем , н йбільше відхилення від клім тичної норми вл стиве перев жно теплим місяцям року (т бл. 4). 2007-2009рр. у орногірському л ндш фті н йбільше перевищення клім тичної норми кількості оп дів спостеріг ли в січні $(61,2$ мм), березні $(108,6)$ і липні $(82,5$ мм), у юбіжнянському - у березні (24,7 мм), липні (75,3) т жовтні (53,5 мм). н ліз відхилення від клім тичної норми кількості оп дів між двом л ндш фт ми свідчить про те, що н йбільші відмінності х р ктерні для січня, березня і тр вня, причому відхилення від клім тичної норми для зг д них місяців є вищим у орногірському л ндш фті, що певною мірою можн пояснити більшою кількістю оп дів у цьому л ндш фті і відповідно, більшим 
відхиленням від клім тичної норми (див. т бл. 4). голосимо, що у орногірському л ндш фті н йбільше відхилення середньої кількості оп дів з 2007-2009 pр. від їхньої клім тичної норми х р ктерне для березня і липня, в юбіжнянському - для липня і жовтня (див. т бл. 4).

блиця 3

ереднє зн чення темпер тури повітря по місяцях з період 2007-2009 pp.

\begin{tabular}{|c|c|c|c|c|c|c|}
\hline \multirow[t]{2}{*}{ ісяці } & \multicolumn{3}{|c|}{$\begin{array}{l}\text { орногірський л ндш фт } \\
\text { (мст ожижевськ ) }\end{array}$} & \multicolumn{3}{|c|}{$\begin{array}{l}\text { юбіжнянський л ндш фт } \\
\text { (мст ремч ) }\end{array}$} \\
\hline & $\begin{array}{l}\text { середня } \\
\text { темпер - } \\
\text { тур } \\
\text { повітря, } \\
\circ\end{array}$ & $\begin{array}{l}\text { клім тичн } \\
\text { норм тем- } \\
\text { пер тури } \\
\text { повітря, }\end{array}$ & $\begin{array}{l}\text { відхилення } \\
\text { від клім тич- } \\
\text { ної норми се- } \\
\text { редньої тем- } \\
\text { пер тури по- } \\
\text { вітря, 。 }\end{array}$ & $\begin{array}{l}\text { середня } \\
\text { темпер - } \\
\text { тур по- } \\
\text { вітря, }^{\circ}\end{array}$ & $\begin{array}{l}\text { клім тичн } \\
\text { норм тем- } \\
\text { пер тури } \\
\text { повітря, }\end{array}$ & $\begin{array}{l}\text { відхилення } \\
\text { від клім - } \\
\text { тичної нор- } \\
\text { ми серед- } \\
\text { ньої темпе- } \\
\text { р тури по- } \\
\text { вітря, }\end{array}$ \\
\hline ічень & $-4,5$ & $-6,4$ & 1,9 & $-0,1$ & $-3,5$ & 3,4 \\
\hline ютий & $-5,3$ & $-5,9$ & 0,6 & $-0,1$ & $-2,3$ & 2,2 \\
\hline ерезень & $-2,3$ & $-3,3$ & 1,0 & 3,3 & 1,6 & 1,7 \\
\hline вітень & 3,2 & 1,8 & 1,4 & 8,7 & 7,0 & 1,7 \\
\hline р вень & 8,2 & 6,9 & 1,3 & 13,4 & 11,8 & 1,6 \\
\hline ервень & 11,7 & 9,7 & 2,0 & 16,7 & 14,9 & 1,8 \\
\hline ипень & 13,7 & 11,3 & 2,4 & 18,2 & 16,5 & 1,7 \\
\hline ерпень & 14,4 & 11,7 & 2,7 & 17,9 & 16,0 & 1,9 \\
\hline ересень & 8,1 & 8,1 & 0 & 12,6 & 12,8 & $-0,2$ \\
\hline овтень & 4,2 & 4,1 & 0,1 & 8,3 & 8,0 & 0,3 \\
\hline истоп д & 0,0 & $-1,1$ & 1,1 & 3,9 & 1,7 & 2,2 \\
\hline рудень & $-3,3$ & $-4,8$ & 1,5 & $-1,2$ & $-1,4$ & 0,2 \\
\hline
\end{tabular}

блиця 4

ереднє зн чення місячної кількості оп дів $з$ період 2007-2009 pp.

\begin{tabular}{|c|c|c|c|c|l|c|}
\hline \multirow{2}{*}{ ісяці } & \multicolumn{3}{|c|}{$\begin{array}{l}\text { орногірський л ндш фт } \\
\text { (мст ожижевськ }\end{array}$} & \multicolumn{3}{|c|}{$\begin{array}{l}\text { обіжняський л ндш фт } \\
\text { (мстч }\end{array}$} \\
\cline { 2 - 7 } & $\begin{array}{l}\text { середня } \\
\text { кількість } \\
\text { оп дів, мм }\end{array}$ & $\begin{array}{l}\text { клім тичн } \\
\text { норм } \\
\text { кількості } \\
\text { оп дів, мм }\end{array}$ & $\begin{array}{l}\text { відхилення } \\
\text { від клім - } \\
\text { тичної нор- } \\
\text { ми кількос- } \\
\text { ті оп дів, мм }\end{array}$ & $\begin{array}{l}\text { середня } \\
\text { кількість } \\
\text { оп дів, мм }\end{array}$ & $\begin{array}{l}\text { клім тичн } \\
\text { норм } \\
\text { кількості } \\
\text { оп дів, мм }\end{array}$ & $\begin{array}{l}\text { відхилення } \\
\text { від клім тич- } \\
\text { ної норми } \\
\text { кількості } \\
\text { оп дів, мм }\end{array}$ \\
\hline ічень & 137,8 & 76,6 & 61,2 & 39,1 & 31,8 & 7,3 \\
\hline ютий & 105,7 & 84,5 & 21,2 & 34,2 & 32,7 & 1,5 \\
\hline ерезень & 201,8 & 93,2 & 108,6 & 71,1 & 46,4 & 24,7 \\
\hline вітень & 100,0 & 98,5 & 1,5 & 73,3 & 73,4 & $-0,1$ \\
\hline р вень & 171,0 & 136,5 & 34,5 & 92,7 & 119,0 & $-26,3$ \\
\hline ервень & 168,7 & 179,7 & $-11,0$ & 134,8 & 144,7 & $-9,9$ \\
\hline ипень & 260,2 & 177,7 & 82,5 & 236,7 & 161,4 & 75,3 \\
\hline ерпень & 103,5 & 134,2 & $-30,7$ & 96,0 & 102,5 & $-6,5$ \\
\hline ересень & 134,3 & 111,4 & 22,9 & 110,2 & 82,3 & 27,9 \\
\hline овтень & 152,8 & 97,5 & 55,3 & 104,3 & 50,8 & 53,5 \\
\hline истоп д & 126,5 & 105,9 & 20,6 & 35,7 & 35,9 & $-0,2$ \\
\hline рудень & 118,9 & 102,0 & 16,9 & 48,3 & 40,3 & 8,0 \\
\hline
\end{tabular}


йвологішим місяцем року щодо клім тичної норми оп дів 3 2007-2009 pp. у орногірському л ндш фті є березень (н 108, мм більше від норми), в юбіжнянському - липень (75,3 мм). окремі місяці кількість оп дів є меншою від клім тичної норми. Йсухішим місяцем року з період 2007-2009 рр. щодо клім тичної норми кількості оп дів у орногірському л нш фті є серпень (н 30,7 мм є менше від клім тичної норми), в юбіжнянському - тр вень (26,3 мм).

тже, викон ний порівняльний н ліз темпер тури повітря і кількості оп дів 3 період 2007-2009 рр. з їхньою клім тичною нормою свідчить про збільшення зн чень цих метеорологічних величин як для исокогірно- олонинської, т к і для изькогірнокибової фізико-геогр фічних обл стей кр їнських рп т уб сейні р. рут. $2007-$ 2009 pp. у орногірському високогірному л ндш фті темпер тур повітря бул вищою від клім тичної норми н $1,3^{\circ}$, в юбіжнянському низькогірному - н $1,6^{\circ}$. ількість оп дів порівняно з 1961-1990рp. у орногірському л ндш фті бул більшою н 383,6 мм ( бо н 27,4 \%), у юбіжнянському - н 155,2 мм ( бо н 16,8 \%).

н ліз темпер тури повітря періоду 2007-2009 pр. по сезон х року доводить, що у исокогірно- олонинській обл сті кр їнських рп т у б сейні р. рут н йбільше перевищення клім тичної норми темпер тури повітря спостеріг ли влітку (н $2,4^{\circ}$ ),

у изькогірно- кибовій взимку (н $1,9^{\circ}$ ). йбільше перевищення клім тичної норми кількості оп дів по сезон х періоду 2007-2009 pp. у орногірському високогірному л ндш фті з фіксов не н весні (н 146,2 мм, ( бо 44,8 \%), у юбіжнянському низькогірному - восени (н 81,2 мм, ( бо 48,0 \%).

ослідження темпер тури повітря періоду 2007-2009 рр. по місяцях свідчить про те, що у исокогірно- олонинській обл сті кр їнських рп т у б сейні р. рут н йбільше перевищення клім тичної норми темпер тури повітря простежув лося у серпні (н $\left.2,7^{\circ}\right)$, у изькогірно- кибовій - у січні (н 3,4 ${ }^{\circ}$ ). йбільше перевищення клім тичної норми кількості оп дів по місяцях з 2007-2009 pp. у орногірському високогірному л ндш фті з реєстров не у березні (н 108,6 мм, ( бо 116,5\%), у юбіжнянському низькогірному - у липні (н 75,3 мм, ( бо 46,7 \%). більшення кількості оп дів пон д клім тичну норму, н н шу думку, може ст ти причиною ктивіз ції зсувів, бокової ерозії, п водків і селів.

1. ойченко . . лоб льні і регіон льні колив ння (зміни) клім ту т можливі екологічні н слідки від них н території кр їни: н півемпіричні моделі, сцен рії: втореф дис. н здобуття н ук. ступеня доктор геогр. н ук/ — . ойченко. - дес , 2005. - 35 с.

2. ндри нов . . ертик льн я термическ я зон льность оветских рп т/ . . ндри нов // уч. 3 писки ьвов. ун-т . - еогр. сб. - 1957. ып. 4. - . 189-198

3. ндрінов . . лім т// рирод кр їнських рп т/ . . ндрі нов. - ьвів: вид-во ьвів. ун-ту, 1968. - .87-101.

4. учинский . . лим т кр инских рп т / . . учинский, . . олев х , . . оржов. . : ук. думк , 1971.

5. ельник . . кр їнські рп ти. колого-л ндш фтозн вче дослідження / . . ельник ьвів: вид-во ьвів. ун-ту, 1999. - 196 с.

6. ельник . . о пит ння рекре ційної оцінки метеоумов лісистого середньогір'я орногори в б сейні річки рут / . . ельник, . . ерезяк // ізичн геогр фія т геоморфологія. - ., 2008. ип. 54. . . 183-186. 
7. ельник . . ізико-геогр фічні передумови, дин мік т н слідки к т строфічного липневого п водк 2008 року у верхів'ї річки рут / . . ельник, . . убер, . . ушняк, . . остів, . . ерезяк // існик ьвів. ун-ту. ерія геогр. - 2009. ип. 37. - . 136-151.

8. етеорологические ежемесячники. - . : : идрометеоизд т, 1961-1991 гг. - ып. 10.

9. оргоч . . ірські л ндш фти т їх мезоклім тичні вл стивості. втореф. дис. н здобуття тупеня к нд. геогр. н ук / . . оргоч. - ., 2001. - 19 с.

10. оргоч . . езоклім тичні особливості кр їнських рп т/ . . оргоч// укові з писки інницького держ вного пед гогічного університету імені их йл оцюбинського : зб. н ук. пр ць. ип. 1: еогр фія. - інниця, 2000. - .27-32.

11. $y x$. ермічні вл стивості топоклім ту рп тського природного н ціон льного п рку / ух // існ. ьвів. ун-ту. ерія геогр. ип. 35 . ьвів, ид в. центр ьвів. н ц. ун-ту ім. в н p нК . 2008. - .251-266.

12. $\mathrm{cm}$ пиук . . иноптико-ст тистичний метод прогнозу різких змін темпер тури повітря всередині місяця н території кр їни у теплий період року: втореф. дис. н здобуття н ук. ступеня к нд. геогр. н ук/ . . ст пчук. - ., 2002. -20 с.

13. ердюченко . . р метриз ція тр нсформ ції регіон льних клім тичних полів кр їни в умов х глоб льного потепління. втореф. дис. н здобуття н ук. ступеня к нд. геогр. н ук / . . ердюченко. - дес , 2006. - 18 с.

14. кринник . . е етод визн чення д т стійких переходів темпер тури повітря через фіксов ні зн чення т тенденції ї змін в умов х суч сного клім ту. втореф. дис. н здобуття н ук. ступеня к нд. геогр. н ук / . . кринник. - ., 2009. - 20 с.

15. убер . . ин мік клім тичних умов орногірського і юбіжнянського л ндш фтів у другій половині ст. / . . убер, . . ерезяк // ізичн геогр фія т геоморфологія. - ., 2010. - ип. 1. (58). - .307-319.

16. ежим доступу до джерел : http://mosmeteo.hmn.ru.

17. ежим доступу до джерел :

http://meteopathy.ru/meteofaktory/klimaticheskaya-norma-temperatury-vozduxa

18. ежим доступу до джерел :

http://meteopathy.ru/meteofaktory/klimaticheskaya-norma-kolitshestva-osadkov.

m ття: н дійшл до редколегії 07.09.2010 прийнят до друку 20.09.2011

\title{
THE TENDENCIES OF AIR TEMPERATURE AND PRECIPITATION IN THE MOUNTAINOUS PART OF THE PRUT RIVER BASIN FOR THE YEARS 2007-2009
}

\author{
P. Shuber, V. Berezyak \\ Ivan Franko National University of Lviv, \\ . Doroshenko St., 41, UA - 79000 Lviv, Ukraine
}

Based of the Pozhyzhevs'ka and Yaremche meteorologie Stations data, the air temperature climatic norm and the precipitation have been determinated for 1961-1990 years. The deviation in comparison with the average air temperature and precipitation the 2007-2009 years from their climatic norm for the Chornohora Landscape of the Highland Pasture and the Liubizhnia Landscape of the Lowland-LowEarth-Lump physico-geographic areas of the Ukrainian Carpathians in the River Prut Basion has been provided for the tendencies analysis of climate change in the study area.

The norm climatic value for the air temperature overrun on $1.3^{\circ}$ at Chornohora Landscape (Pozhyzhevs'ka meteorologic Station) and $1.6^{\circ}$ at Liubizhnia Landscape (Yaremche meteorological Station) has been identified for period 2007-2009. The overrun of the norm precipitation consist $383.6 \mathrm{~mm}$ in the first and $155.2 \mathrm{~mm}$ in the second study areas.

Key words: precipitation, air temperature, climatic norm, dynamics, Landscape. 


\section{7-2009}

\section{. убер, . ерезяк}

ввовский н цион льный университет имени в н р нко

ул. орошенко, 41, г. ввов, $79000 к р и н$

о д нным метеост нций ожижевск я и ремче определен клим тическ я норм темпер туры воздух и количеств ос дков з период 1961-1990 гг. и про н лизиров но отклонение средней темпер туры воздух и количеств ос дков з период 2007-2009 гг. от их клим тической нормы для ерногорского л ндш фт ысокогорно- олонинской и юбижнянского л ндш фт изкогорно- кибовой физико-геогр фических обл стей кр инских рп т в $б$ ссейне реки рут для выяснения тенденций клим тических изменений территории исследов ния.

ля период 2007-2009 гг. з фиксиров но превышение клим тической нормы темпер туры воздух н $1,3^{\circ}$ в ерногорском л ндш фте (мст ожижевск я) и н $1,6^{\circ}$ в юбижнянском л ндш фте (мст ремче). ревышение количеств ос дков н д их клим тической нормой в ерногорском л ндш фте сост вляет 383,6 мм, в юбижнянском - 155,2 мм.

лючевые слов : тмосферные ос дки, темпер тур воздух , клим тическ я норм , дин мик , л ндш фт. 